Asian-Australasian Journal of

Food Safety and Security

ISSN 2523-1073 (Print) 2523-2983 (Online)

www.ebupress.com/journal/aajfss

\title{
Article \\ A comparative profitability of pineapple-mono crop and pineapple intercrops of Modhupur area in Tangail district of Bangladesh
}

\author{
Tipu Sultan ${ }^{1}$, Syful Islam ${ }^{2 *}$, Md. Shofiqul Islam³ ${ }^{3}$ Md. Kamruzzaman ${ }^{3}$ and Md. Imrul Kaysar ${ }^{4}$ \\ ${ }^{1}$ Department of Agricultural Economics, Bangladesh Agricultural University, Mymensingh, Bangladesh \\ ${ }^{2}$ Agricultural Economics Division, Bangladesh Institute of Nuclear Agriculture (BINA), Mymensingh, \\ Bangladesh \\ ${ }^{3}$ Agricultural Economics Division, Bangladesh Sugarcrop Research Institute (BSRI), Ishwardi, Pabna, \\ Bangladesh \\ ${ }^{4}$ Agricultural Economics Division, Bangladesh Agricultural Research Institute (BARI), Gazipur, Bangladesh
}

*Corresponding author: Syful Islam, Agricultural Economics Division, Bangladesh Institute of Nuclear Agriculture (BINA), Mymensingh, Bangladesh. E-mail: bausyful07@ gmail.com

Received: 31 October 2018/Accepted: 22 November 2018/ Published: 29 November 2018

\begin{abstract}
A survey study was conducted to estimate the cost, returns, relative profitability and practices of Pineapple mono-crop and Pineapple inter-crops production in Madhupur area of Tangail District. Data was collected personally through prepared interview schedule from 60 randomly selected Pineapple growers from Ausnara, Oronkhola, Sonia and Motel bazar union under Madhupur Upazila of Tangail District during July to October 2013. A simple random sampling was followed to select the farmers in the study area. Both tabular and statistical analyses were applied in this study. Cost and return analysis showed that total cost incurred for producing Pineapple mono crop, Pineapple+Papaya and Pineapple+Banana+Aroid were Tk.312849.72, Tk.395894.01 and Tk.377013.25 per hectare respectively. Per hectare net return for Pineapple + Papaya and Pineapple + Banana + Aroid production were Tk.492111.00 and Tk.195704.75 which were higher than that of Pineapple mono crop (Tk.157675.28). On the other hand BCR for Pineapple + Papaya and Pineapple + Banana + Aroid production were 2.24 and 1.52 which were higher than that of Pineapple mono crop (1.50). It represents that both pineapple mono-crop and pineapple inter-crops production are profitable among them Pineapple-inter crops cropping pattern is more profitable then Pineapple-mono crop. About $80 \%$ of pineapple growers grow papaya, banana, zinger, turmeric and aroids as intercrops with pineapple. The study identified some crucial problems and probable solutions suggested by the farmer. Finally, some policy recommendations were suggested and avenues for further research were shown.
\end{abstract}

Keywords: profitability; yield gap; constraints; strategies; pineapple

\section{Introduction}

Pineapple is one of the major commercial and popular fruits in Bangladesh because of its distinct flavor, pleasant aroma, delicious taste, nutritional and medicinal values. Giant kew and Honey Queen are the two popular and commercially important varieties grown in Bangladesh, but they cover the area concentrated in Tangail, Sylhet, Chittagong, Rangamati Hilly tract and Comilla district. Bangladesh produces 15.8thousand MT of pineapple per annum from 14.85 thousand hectares of land. In respect of total production it ranks $4^{\text {th }}$ among the major fruits grown in this country (BER, 2016).

In addition to serving as food, with its natural sweetness, the pineapple has served in history as a symbol and an artistic motif. According to Levins (2004), the rarity, reputation, expense, and visual attractiveness of the pineapple made it an item of celebrity and the "ultimate exotic fruit." Pande (2009) stated that processing of fruit and vegetables is getting higher attention for enabling farmers to get higher price for the produce. 
Internationally, countries like the U.S, India are into large scale processing of fruits into various forms. Altman and Eite-man (2009) stated that about 1.8 million tonnes of watermelon were produced in the U.S. The pineapple was so coveted and uncommon that in the 1600s King Charles II of England posed receiving a pineapple as a gift in an official portrait. In colonial America, the pineapple became a symbol of hospitality, and served as the pinnacle of an entertaining household's feast, even being rented to households during the day for display on the table and then sold to more affluent clients who actually ate it (Levins, 2004). As a symbol of hospitality and friendship, the pineapple became a favorite motif of architects, artisans, and craftsman in the American colonies, and would be seen on the main gate posts of mansions, in the weather vanes of public buildings, and on walls, canvas mats, tablecloths, napkins, the backs of chairs, in china, and so forth (Levins, 2004). Some have claimed that pineapple has benefits for some intestinal disorders, while others claim that it helps to induce childbirth when a baby is overdue. These enzymes can be hazardous to someone suffering from certain protein deficiencies or disorders. Pineapple can also be used to enhance digestion. The specific objectives of the study are: i) to document the socio demographic characteristics of farmers growing Pineapple mono crop and Pineapple inter crops; ii) to assess the relative profitability of adopting Pineapple inter crops over Pineapple mono cropping pattern; iii) to determine the factors influencing gross returns of Pineapple mono crop and Pineapple inter crops production; iv) to identify the problems and constraints associated with the production and marketing of Pineapple mono crop and Pineapple inter crops; and v) to suggest some policy guidelines for further implementation.

\section{Materials and Methods}

The reliability of a scientific research depends to a great extent on the appropriate methodology used in the study. Methodology refers to the way in which a research is accomplished. This hilly area was selected from Modhupur Upazila of Tangail district in Bangladesh. In fact, five adjacent villages namely Maguntinogor, Jalchatra, Oronkhola, Chunia, Ausnara, and have purposively been selected for the research investigation. Hilly area was chosen because selected five villages have similar types of land and soil characteristics. Therefore, 60 farmers selected randomly from each of the selected cropping patterns (Table 1).

Table 1. Distribution of sample farmers of the study area.

\begin{tabular}{lllll}
\hline Selected villages & \multicolumn{2}{c}{ Sample size (Nos.) } & Total sample size \\
\cline { 2 - 5 } & Pineapple farmer & $\begin{array}{l}\text { Pineapple-Papaya } \\
\text { farmer }\end{array}$ & $\begin{array}{l}\text { Pineapple-Banana- } \\
\text { Aroid farmer }\end{array}$ & \\
\hline Maguntinogor & 4 & 4 & 4 & 12 \\
Oronkhola & 4 & 4 & 4 & 12 \\
Jalchatra & 4 & 4 & 4 & 12 \\
Chunia & 4 & 4 & 4 & 12 \\
Ausnara & 4 & 4 & 4 & 12 \\
Total & $\mathbf{2 0}$ & $\mathbf{2 0}$ & $\mathbf{2 0}$ & $\mathbf{6 0}$ \\
\hline
\end{tabular}

\subsection{Descriptive statistics}

The descriptive statistics technique was used to determine averages, percentages, means, deviations, ratios, etc. Descriptive statistics were employed for testing the hypothesis (a). It is very simple in calculation, widely used and easy to understand. Descriptive statistics technique included in socioeconomic profiles of Pineapple mono crop and Pineapple inter crops farmers, production practices and input use, costs and returns of pineapple mono crop and Pineapple inter crops farming. Profitability can be measured on yearly basis or over or the lifespan of an investment whiles the lifespan profitability measure is employed to enable in re-source allocation decision. Return on profit margin and return on equity are also well known profitability measures (Ross et al., 2001). Once cost and benefits has been identified, if they are to be compared, they must be valued. Underlying all financial analysis is the assumption that prices reflect value, or can be adjusted to do so (Gittinger, 1996).

\subsection{Activity budgets}

Activity budget is the most common method in determining and comparing the profitability of enterprise activities followed the concerned farmers taking into account different techniques of production. Profit is defined as the difference between the total revenue and total cost. The following algebraic profit $(\boldsymbol{\pi})$ equation was employed for testing the set hypothesis (b). In fact, this equation was employed to prepare activity budgets of the concerned selected crops like Pineapple mono crop and Pineapple inter crops from the view point of individual farmers: 


$$
\begin{aligned}
& \boldsymbol{\pi}=\mathrm{TR}-\mathrm{TC} \\
& \mathrm{Or}, \pi=\mathrm{TR}-(\mathrm{VC}+\mathrm{FC}) \\
& \pi=\sum Q_{y} . P_{y}+\sum Q_{b} \cdot P_{b}-\sum_{i=1}^{n}\left(X_{i} \cdot P_{x i}\right)-T F C
\end{aligned}
$$

Where,

$\pi=$ Net returns $(\mathrm{Tk} / \mathrm{ha})$;

$Q_{y}=$ Total quantity of the relevant outputs $(\mathrm{kg} / \mathrm{ha})$;

$P_{y}=$ Per unit prices of the relevant outputs $(\mathrm{Tk} / \mathrm{kg})$;

$Q_{b}=$ Total quantity of the concerned by-products $(\mathrm{kg} / \mathrm{ha})$;

$P_{b}=$ Per unit prices of the relevant by-products $(\mathrm{Tk} / \mathrm{kg})$;

$X_{i}=$ Quantity of the concerned $i^{\text {th }}$ inputs;

$P_{x i}=$ Per unit price of the relevant $i^{t h}$ inputs;

TFC $=$ Total fixed cost involved in the concerned crops production; $\mathrm{i}=1,2,3, \ldots, \mathrm{n}$ (number of inputs).

\section{Results and Discussion}

One of the most important aspects of this study was to evaluate the profitability of selected crop. A quick way to assess the profitability was to calculate net return and gross margin. To the value of net return, at first the cost of production and then the value of output (gross return) have been calculated. First of all, activity budgets of Pineapple mono crop and then Pineapple inter crops were presented.

\subsection{Estimation of cost}

Farmers had to pay cash for the purchased inputs like fertilizers, insecticides/pesticides, vitamin, irrigation water charge etc., and it was, in fact, very easy and straightforward to calculate the costs of these items. The average cost of seedling for Pineapple mono crop was Tk.66000.00 per hectare which covered 21.1 percent of total cost (Table 2). The costs of seed for per hectare Pineapple inter crops were Tk. 64606.00 and Tk 63618.00 for (Pineapple+papaya) and (Pineapple+Banana+Aroid), respectively which covered 16.32 percent and 16.87 percent respectively of total cost (Table 3 and Table 4). In the study area, on an average wage rate was Tk. 300.00 per man-day during the study period.

From Table 2, Table 3 and Table 4 it can be seen that Pineapple mono crop and Pineapple inter crops growers used on an average $800 \mathrm{~kg} / \mathrm{ha}$ of Urea, $650 \mathrm{~kg} / \mathrm{ha}$ of TSP, $500 \mathrm{~kg} / \mathrm{ha}$ and $600 \mathrm{~kg} / \mathrm{ha}$ of MOP and $800 \mathrm{~kg} / \mathrm{ha}$ of Urea, $600 \mathrm{~kg} / \mathrm{ha}$ of TSP, $450 \mathrm{~kg} / \mathrm{ha}$ and $600 \mathrm{~kg} / \mathrm{ha}$ of MOP for (Pineapple + papaya) and $600 \mathrm{~kg} / \mathrm{ha}$ of Urea, 500 $\mathrm{kg} / \mathrm{ha}$ of TSP, $400 \mathrm{~kg} / \mathrm{ha}$ and $500 \mathrm{~kg} / \mathrm{ha}$ of MOP for (Pineapple+Banana+Aroid) respectively (Mondal, 2000). The average prices of Urea, TSP, MOP and Gypsum were Tk. 810, Tk. 1200, Tk. 7.20 and Tk. 550 per 50 kg, respectively. Per hectare insecticide cost was Tk 4950.00 for Pineapple mono crop which was 1.6 percent of the total gross costs and Tk 4690.00 and Tk. 35430 for (Pineapple + papaya) and (Pineapple + Banana+Aroid) which was 1.18 and 9.4 percent of the total gross costs respectively (Roy et al., 1986). However, per hectare cost of irrigation for (Pineapple+Banana+Aroid) production Tk 6300.00 which constituted 1.67 percent of the total gross costs (Table 4).

It can be observed from Table 2 that Pineapple mono crop growers used on an average 4 times and total vitamin cost is Tk. 19600.00, which 6.26 percent of the total gross costs of Pineapple mono crop production. Tables 3 and 4 reveal that Pineapple inter crops growers used on an average 4 times and total vitamin cost is Tk.16400/ha and Tk. 19680/ha for (Pineapple + papaya) and (Pineapple+Banana+Aroid) crop. The total land cost for Pineapple mono crop, (Pineapple + papaya) and (Pineapple+Banana+Aroid) crop is Tk. 9898/ha which was $3.16,2.5$ and 2.63 percent of the total gross costs respectively. In the study area, on an average marketing rate was Tk. 2.50 per pineapple during the study period. It can be observed from Table 6.1 that Pineapple mono crop growers used on an average 33000 pieces of Pineapple cost is Tk. 82500/ha, which 26.37 percent of the total gross costs of Pineapple mono crop production. Pineapple inter crops growers used on an average 60525 pieces and51920 pieces of Pineapple inter crops, cost is Tk. 151312.00/ha and Tk. 129800.00/ha for (Pineapple+papaya) and (Pineapple+Banana+Aroid) which is 38.22 percent and 34.43 percent respectively. It is seen that the marketing cost for Pineapple inter crops cultivation was much higher than Pineapple mono crops cultivation. In the study area interest on operating capital per hectare were Tk. 21826.725 which was 6.98 percent of total gross costs of production of Pineapple mono crop and Tk. 27620.00 and Tk. 26303.25 for (Pineapple + papaya) and (Pineapple + Banana + Aroid) production which was 6.98 percent and 6.98 percent respectively (Table 2, Table 3 and Table 4). In our country land tax is imposed on those farmers whose farm 
size is greater than 33 bigha, but in the study area the sampled farmer's farm size was less than 33 bigha. That's why the cost of land tax was ignored in the study. Per hectare total cost of Pineapple mono crop is Tk. 312850 and Pineapple inter crops production were estimated at Tk. 395894 for (Pineapple+papaya) and Tk. 377013.247 for (Pineapple+Banana+Aroid) respectively (Table 2, Table 3 and Table 4).

\subsection{Estimation of gross return}

Per hectare yield of Pineapple mono crop was found to be 32450 peaces Table 2 shows that per peace values of main product of Pineapple was Tk. 14.50 and the gross return was Tk. 470525.00 per hectare (Table 2). It can be seen from Tables 3 and 4 that gross returns for Pineapple inter crops farming were Tk. 888005.00 for (Pineapple + papaya) and Tk. 572718.00 for (Pineapple + Banana + Aroid) respectively (Kayitesi, 2011). It is noted here that for Pineapple inter crops there was no by product so gross return was calculated by multiplying the total amount of product with respective price. In the present study, gross margin was estimated at Tk. 179502.00, Tk. 519731.50 and Tk.222008.00 per hectare for Pineapple mono crop, (Pineapple + papaya) and (Pineapple + Banana + Aroid), respectively. Per hectare net returns of Pineapple mono crop, (Pineapple + papaya) and (Pineapple + Banana + Aroid) were Tk. 157675.28, Tk. 492111.00 and Tk. 195704.75 respectively (Table 2, Table 3 and Table 4).

Table 2. Activity budgets: per hectare pineapple mono crop production.

\begin{tabular}{|c|c|c|c|c|}
\hline Items of costs/ returns & Total quantity/ha & Per unit price(Tk.) & Costs/returns (Tk./ha) & $\%$ of total \\
\hline \multicolumn{5}{|l|}{ A. Gross Returns } \\
\hline $\begin{array}{l}\text { Main product } \\
\text { (Pineapple) }\end{array}$ & 32450 peaces & 14.50 & $4,70,525.00$ & 100 \\
\hline By-product & n.a & - & - & - \\
\hline Total returns & - & - & $4,70,525.00$ & 100 \\
\hline \multicolumn{5}{|l|}{$\begin{array}{l}\text { B. Gross Costs } \\
\text { C. Variable Costs }\end{array}$} \\
\hline Vitamin & 2 times & 9800/time & $19,600.00$ & 6.26 \\
\hline Seedlings & 33000 peaces & 2/peace & $66,000.00$ & 21.10 \\
\hline Land preparation & 36 Man-day & 300/Man-day & $10,800.00$ & 3.45 \\
\hline Transplanting & 33000 peaces & $0.5 /$ peace & $16,500.00$ & 5.27 \\
\hline Weeding & 26 Man-day & 300/Man-day & 7800.00 & 2.49 \\
\hline Harvesting & 45 Man-day & 300/Man-day & $13,500.00$ & 4.32 \\
\hline labour & - & - & $48,600.00$ & 15.53 \\
\hline Marketing & 33000 peaces & $2.5 /$ peace & $82,500.00$ & 26.37 \\
\hline Urea & 16 bags & $810 / \mathrm{bag}$ & $12,960.00$ & 4.14 \\
\hline TSP & 13 bags & $1200 / \mathrm{bag}$ & $15,600.00$ & 4.99 \\
\hline MOP & 12 bags & 720/bag & 8640.00 & 2.76 \\
\hline Gypsum & 10 bags & $550 / \mathrm{bag}$ & 5500.00 & 1.76 \\
\hline Fertilizer cost & - & - & $42,700.00$ & 13.65 \\
\hline Pesticides & n.a & - & 4950 & 1.58 \\
\hline Land cost & n.a & - & 9898.00 & 3.16 \\
\hline Others & n.a & - & $16,775.00$ & 5.36 \\
\hline Total & - & - & $2,91,023.00$ & 93.02 \\
\hline \multicolumn{5}{|l|}{ D. Fixed Costs } \\
\hline Interest on OC & - & @ 10\% & $21,826.73$ & 6.98 \\
\hline Total & - & - & $21,826.73$ & 6.98 \\
\hline E. Total costs & & - & 312849.72 & 100.00 \\
\hline F. Gross Margin (A-C) & & - & $1,79,502.00$ & - \\
\hline G. Net Return (A-E) & & - & $1,57,675.28$ & - \\
\hline
\end{tabular}


Table 3. Activity budgets: per hectare pineapple-papaya production.

\begin{tabular}{lllll}
\hline Items of costs/ returns & Total quantity/ha & Per unit price(Tk) & Costs/returns (Tk/ha) & \% of total \\
\hline A. Gross Returns & & & & \\
Pineapple & 31850 peaces & 14.50 & $4,61,825.00$ & 52.01 \\
Papaya & $71030 \mathrm{~kg}$. & 6.00 & $4,26,180.00$ & 47.99 \\
By-product & n.a & - & - & - \\
Total returns & & & $8,88,005.00$ & 100 \\
B. Gross Costs & & & \\
C. Variable Costs & 2/times & $8200 /$ time & $16,400.00$ & 4.14 \\
Vitamin & 32303/ peaces & $2 /$ peace & $64,606.00$ & 16.32 \\
Seedlings(Pineapple) & 2884/ peaces & $2 /$ peace & 5768.00 & 1.457 \\
Seedlings(Papaya & $40 /$ Man-day & $300 /$ Man-day & $12,000.00$ & 3.03 \\
Land preparation & $41433 /$ peaces & $0.5 /$ peace & $20,716.50$ & 5.23 \\
Transplanting & 26/ Man-day & $300 /$ Man-day & 7800.00 & 1.97 \\
Weeding & $48 /$ Man-day & $300 /$ Man-day & $14,400.00$ & 3.64 \\
Harvesting & - & - & $54,916.50$ & 13.87 \\
Labour cost & $60525 /$ peaces & $2.5 /$ peace & $1,51,312.50$ & 38.22 \\
Marketing & 16 bags & $810 /$ bag & $12,000.00$ & 3.03 \\
Urea & 12 bags & $1200 /$ bag & $20,716.50$ & 5.23 \\
TSP & 12 bags & $720 /$ bag & 8640.00 & 2.18 \\
MOP & 9 bags & $550 /$ bag & 4950.00 & 1.25 \\
Gypsum & - & - & $46,306.50$ & 11.70 \\
Fertilizer cost & n.a & - & 4690.00 & 1.18 \\
Pesticides & n.a & - & 9898.00 & 2.50 \\
Land cost & n.a & - & $14,376.00$ & 3.63 \\
Others & - & - & $3,68,273.50$ & 93.02 \\
Total & & & $27,620.51$ & \\
D. Fixed Costs & - & - & 27620.51 & 6.98 \\
Interest on OC & - & - & 395894.01 & 6.98 \\
Total & & 519731.50 & 100.00 \\
E. Total costs & & 492111.00 & - \\
F. Gross Margin (A-C) & & & - \\
G. Net Return (A-E) & & & & \\
\hline
\end{tabular}

Table 4. Activity budgets: per hectare pineapple-banana-aroid production.

\begin{tabular}{lllll}
\hline Items of costs/ returns & Total quantity/ha & Per unit price(Tk.) & Costs/returns (Tk./ha) & \% of total \\
\hline A. Gross Returns & & & & \\
Pineapple & 30837 peaces & 14.00 & $4,31,718.00$ & 75.38 \\
Banana & 375 bunch & 180.00 & $67,500.00$ & 11.79 \\
Aroid & 210 mand & 350.00 & $73,500.00$ & 12.83 \\
By-product & n.a & - & - & - \\
Total returns & - & - & $5,72,718.00$ & 100.00 \\
B. Gross Costs & & & \\
C. Variable Costs & & & \\
Vitamin & 2 times & $9840 /$ time & $19,680.00$ & 5.22 \\
Seedlings(Pineapple) & 31809 peaces & $2 /$ peace & $63,618.00$ & 16.87 \\
Seedlings(Banana & 405 peaces & $2 /$ peaces & 810.00 & 0.21 \\
Seedlings(Aroid) & 18 Mand & $468 /$ Mand & 8424.00 & 2.23 \\
Land preparation & 32 Man-day & $300 /$ Man-day & 9600.00 & 2.55 \\
Transplanting & 32260 peaces & $0.5 /$ peace & $16,130.00$ & 4.29 \\
Weeding & 17 Man-day & $300 /$ Man-day & 5100.00 & 1.35 \\
Harvesting & 42 Man-day & $300 /$ Man-day & $12,600.00$ & 3.34 \\
labor & - & - & $43,430.00$ & 11.52 \\
Marketing & $51920 /$ peaces & $2.5 /$ peace & $1,29,800.00$ & 34.43 \\
Urea & 12 bags & $810 /$ bag & 9720.00 & 2.58 \\
TSP & 10 bags & $1200 /$ bag & $12,000.00$ & 3.18 \\
MOP & 10 bags & $720 /$ bag & 7200.00 & 1.91 \\
Gypsum & 8 bags & $550 /$ bag & 4400.00 & 1.17 \\
Fertilizer cost & - & - & $33,320.00$ & 8.84 \\
\hline
\end{tabular}




\begin{tabular}{lllll}
\hline Items of costs/ returns & Total quantity/ha & Per unit price(Tk.) & Costs/returns (Tk./ha) & \% of total \\
\hline Pesticides & n.a & - & $35,430.00$ & 9.40 \\
Irrigation & 18 & 350 & 6300.00 & 1.67 \\
Land cost & n.a & - & 9898.00 & 2.63 \\
Total & - & - & $3,50,710.00$ & 93.02 \\
D. Fixed Costs & - & & & \\
Interest on OC & - & - & $26,303.25$ & 6.98 \\
Total & & - & $26,303.25$ & 6.98 \\
E. Total costs & - & $37,7,013.25$ & 100.00 \\
F. Gross Margin (A-C) & - & $19,6,539.50$ & - \\
G. Net Return (A-E) & & $1,70,236.25$ & - \\
\hline
\end{tabular}

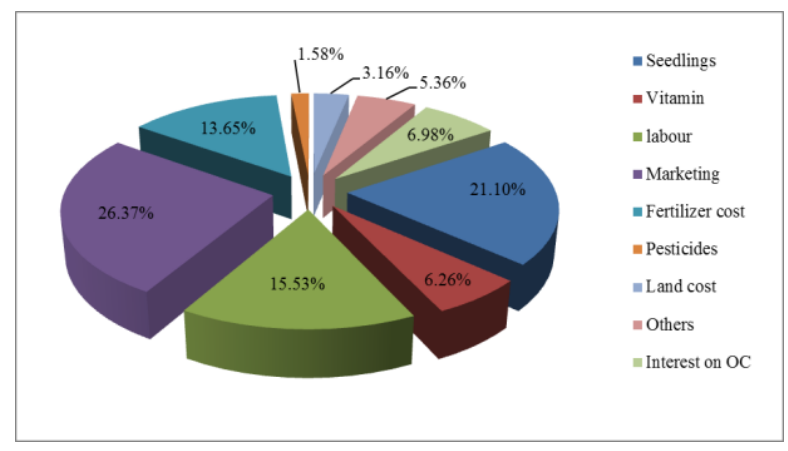

Figure 1. Percentage shares of costs for pineapple mono crop production.

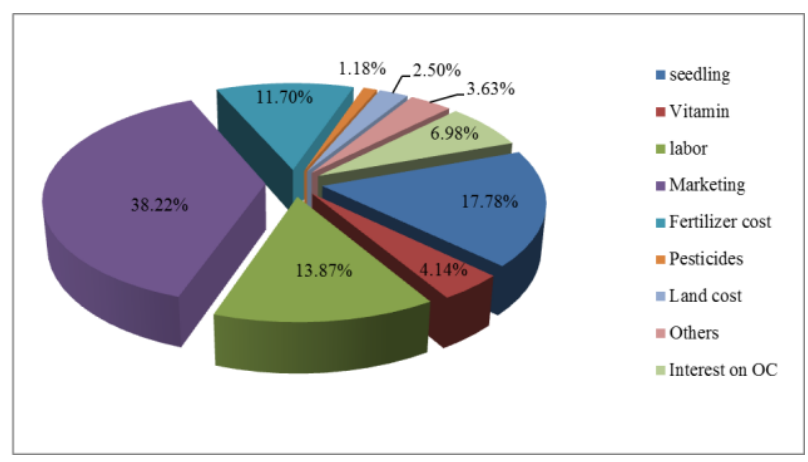

Figure 2. Percentage share of costs for (pineapple + papaya) production.



Figure 3. Percentage share of costs for (pineapple + banana + aroid) production.

The results of Pineapple mono crop, (Pineapple + papaya) and (Pineapple + Banana + Aroid) farming are summarized in Table 5. 
Table 5. Comparative performance of pineapple mono crop, (pineapple + papaya) and (pineapple + banana + aroid) production in the study area.

\begin{tabular}{llll}
\hline Items & Pineapple mono crop & Pineapple + Papaya & Pineapple + Banana + Aroid \\
\hline A. Gross returns (Tk./ha) & $4,70,525.00$ & $8,88,005.00$ & $5,72,718.00$ \\
B. Variable costs (Tk./ha) & $2,91,023.00$ & $3,68,273.50$ & $3,50,710.00$ \\
C. Gross margin (A-B) & $1,79,502.00$ & $5,19,731.50$ & $2,22,008.00$ \\
D. Total costs (Tk./ha) & $3,12,849.72$ & $3,95,894.01$ & $3,77,013.25$ \\
E. Net returns (A-D) & $1,57,675.28$ & $4,92,111.00$ & $1,95,704.75$ \\
\hline
\end{tabular}

Source: Adapted from Table 2, Table 3 and Table 4.

In the present study, gross margin was estimated at Tk. 1,79,502.00 per hectare for Pineapple mono crop production and was estimated at Tk. 5,19,731.50 and Tk. 2,22,008.00 per hectare for (Pineapple + papaya) and (Pineapple+Banana+Aroid) respectively. So gross margin was higher for Pineapple inter crops production.

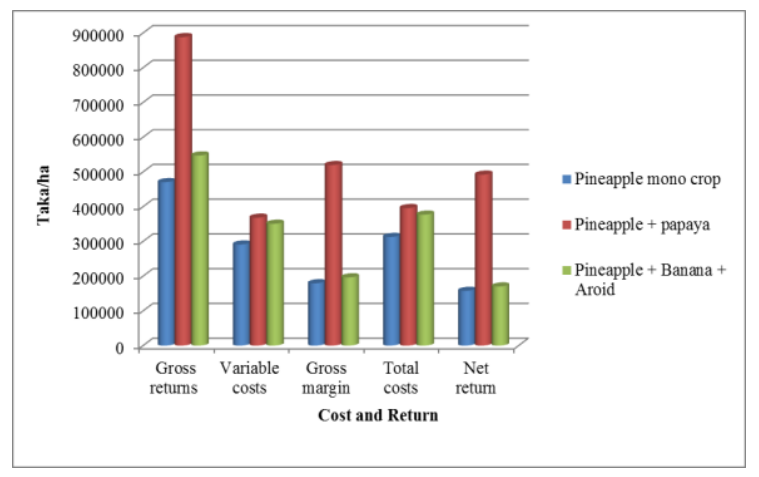

Figure 4. Per hectare return, gross margin, net return of pineapple mono crop, (pineapple + papaya) and (pineapple + banana + aroid) farming.

Net return was higher for Pineapple + papaya crops while it was lower for Pineapple mono crops cultivation. Per hectare net return of Pineapple mono crop was Tk. 1,57,675.28 and for Pineapple inter crops production the net returns were Tk. 4,92,111.00 for (Pineapple + papaya) and Tk. 1,95,704.75 for (Pineapple + Banana + Aroid) respectively.

The result presented in the Table 5 indicates that production of Pineapple mono crop and Pineapple inter crops was profitable from the viewpoints of individual farmers, but there is a difference in profitability.

\subsection{Profitability following different cropping patterns}

As stated earlier, the farmers of the polder area was following two cropping patterns (Pineapple mono crop and Pineapple inter crops). In this sub-section, an attempt has been made to compare the profitability between the followers of Pineapple mono crops and Pineapple inter crops cropping pattern which has been shown in Table 6 .

Table 6. Comparison of profitability following different cropping patterns.

\begin{tabular}{lll}
\hline Cropping pattern & Net return (Tk. /ha/season) \\
\hline A. & Pineapple mono crop & $1,57,675.28$ \\
B. & Pineapple + Papaya & $4,92,111.00$ \\
C. & Pineapple + Banana + Aroid & $1,95,704.75$ \\
& Difference (B-A) & $3,34,435.72$ \\
& Difference (C-A) & $38,029.47$ \\
\hline
\end{tabular}

It can be seen from Table 6 that there is a significant difference in profitability between two categories of farmers, the farmers, who were following the Pineapple inter crops cropping pattern, much higher profit than Pineapple mono crops farmers. The main reason was, as mentioned earlier that per hectare yield of Pineapple inter crops was much higher in polder area than traditional Pineapple mono crops. In fact, Pineapple inter crops farmers got per hectare Tk. 334435.72 for (Pineapple + Papaya) and Tk. 38,029.47 for (Pineapple + Banana + 
Aroid) more profit than the Pineapple mono crops farmers. Figure 6 shows the net returns incurred from different cropping patterns.



Figure 5. Net returns of pineapple mono crop, (pineapple + papaya) and (pineapple + banana + aroid) crops farmers.

\subsection{Benefit cost ratio}

Benefit cost ratio (undiscounted) is a measure to determine the efficiency of resource use which was applied in the present study on the basis of total cost and cash cost. Undiscounted, BCR was found 1.50 on total cost basis for Pineapple mono crops and for Pineapple inter crops it was as 2.24 (Table 7).

Table 7. Comparative costs and returns of pineapple mono crops and pineapple inter crops production.

\begin{tabular}{llll}
\hline Particulars & Pineapple mono crops & Pineapple + Papaya & Pineapple + Banana + Aroid \\
\hline Gross return & 470525.00 & 888005.00 & 572718.00 \\
Total cost & 312849.72 & 395894.01 & 377013.25 \\
BCR (Undiscounted) & 1.50 & 2.24 & 1.52 \\
\hline
\end{tabular}

\section{Problems and Policy Recommendations}

Problems and Constraints of Pineapple mono crops and Pineapple inter crops Production

For the sake of analytical convenience the problems and constraints were classified into four general groups:

(a) Economic problems: Seasonal labour shortage and high wage rate, lack of capital or institutional credit, high price of inputs, lack of good quality seedlings and low price of output (Fakayode et al., 2012);

(b) Technical Problems: Insufficient water availability for irrigation, lack of scientific knowledge and method, lack of extension services, attack of disease and insecticides, attack by monkey and harvesting problem (FAOSTAT 2009);

(c) Marketing problems: Inadequate demand, lack of proper marketing channel, lack of storage facilities and lack of transportation facilities; and

(d) Social Problems: Adulteration of fertilizers and shortage of electricity.

Based on the results of the study some important policy recommendations for Pineapple mono crop and Pineapple inter crops farming arises which are highlighted in this sub-section. First of all, policy on Pineapple mono crop farming and then on Pineapple inter crops are presented here.

i. Newly released high yielding varieties of Pineapple should be popularized in the study area. High quality seedling of those varieties must be available to the farmers in time a cheap rate;

ii. The availability of adulterated fertilizers and seeds in the market must be stopped with immediate effects. The Department of Agriculture Extension (DAE) and law enforcing agency must pay an attention to control malpractices of the dishonest traders;

iii. Training on scientific cultivation of Pineapple mono crop should be imparted to the local farmers by the extension personnel or NGO officials for improving production efficiency;

iv. Labour-saving technology could be expanded in this area for reducing cost of production and improving per hectare yield of rice;

v. Marketing and communication facilities from primary producers to organized markets should be improved for having fair prices of the outputs; and 
vi. A required amount of funds could be allocated for renovation activities of this polder so that repairing works could be done within the shortest possible time. Thus, lives and properties of general people can be saved from natural hazards.

\section{Conclusions}

From the above discussions and the results presented in Table 6.5 clearly indicate that there is wider variation in the profitability of Table 6.5 Comparative costs and returns of Pineapple mono crops and Pineapple inter crops production. It was found that profitability of Pineapple inter crops growing farmers was higher than the profitability of Pineapple mono crop growing farmers. It indicates the rejection of null hypothesis (b). Moreover, it was found from the study area that Pineapple inter crops farmers used more human labour and fertilizer on their field and better yield was realized by the farmers as compared to Pineapple mono crops growing farmers. Pineapple inters crops cultivation provided high return to its high yield Potential thus Pineapple inters crops cropping pattern gaining popularity in the study area very quickly.

\section{Acknowledgements}

We like to acknowledge all of them sincere co-operation for analyzing the samples. We also show our gratitude to those Govt. and private company officers and farmers who help to collect the samples.

\section{Conflict of interest}

None to declare.

\section{References}

Altman A and MA Eiteman, 2009. Optimizing Large-Scale Production of Ethanol from Culled Watermelon Center for Molecular Bio Engineering. University of Cambridge.

BER, 2016. Household Income and Expenditure Survey 2010. Bangladesh Bureau of Statistics. Ministry of Planning, Dhaka.

Fakayode SB, MAY Rahji and ST Adeniyi, 2012. Economic analysis of risks in fruit and vegetable farming in Osun state Nigeria. Bangladesh J. Agril. Res. 37:3.

FAOSTAT, 2009. Top 5 facts sources: Food and Agriculture Organization of the United Nations.

Gittinger JP, 1996. Economic Analysis of Agricultural Project, John Hopkins University Press. Baltimore. 2nd ed. completely revised and expanded.

Kayitesi R, 2011. Factors affecting small scale farmers' pineapple production: the study of Ngoma District, Rwanda. Larenstein University of Applied Sciences. Rwanda.

Lavins R and Pauly D, 2004. Improving the state of coastal areas in the Asia-Pacific region. Coastal Management. 32: 3-15.

Mondal FM, 2000. Production and Storage of Fruits. BAU campus. Mymensingh.

Pande JC, 2009. Watermelon Processing Triple Solar Integrated Device. Central Arid Zone Research Institute.

Ross SA, RW Westerfield and BD Jordan, 2001. Essentials of Cooperate Finance, $3^{\text {rd }}$ ed. NY, America. McGraw-Hill.

Roy R, M Hossain, SK Mitra and TK Bose, 1986. Maharashtra J Hort., 3: 38-73. 